Indonesian Journal of EFL and Linguistics

Vol. 1 No. 2, 2016

eISSN: 2503-4197, pISSN: 2527-5070

www. indonesian-efl-journal.org

DOI: http://dx.doi.org/10.21462/ijefll.v1i2.7

\title{
An Investigation into the Educational Philosophy and Spirituality of Iranian EFL Teachers
}

\author{
Elaheh Suleimani* \\ Department of Foreign Languages and Linguistics, Shiraz University, Shiraz, Iran \\ (M.A in TEFL) \\ e-mail: elahehsuleimani@gmail.com (corresponding author) \\ Rahman Sahragard, Ph.D \\ Department of Foreign Languages and Linguistics, Shiraz University, Shiraz, Iran \\ (Professor) \\ e-mail: rsahragard@rose.shirazu.ac.ir
}

\begin{abstract}
:
Although philosophy and spirituality are related to various branches of disciplines, they have not been subject to focused attention in foreign language teaching. In this paper, schools of educational philosophy, and spirituality in education were connected together to present the stance, viewpoint, and practice of these two constructs in English as foreign language (EFL) Iranian educators. Results indicated that the dominant philosophy of education of Iranian EFL teachers was progressive education. Furthermore, combination of progressive and humanistic philosophies and humanistic philosophy were to some extent established a balance with progressivism. None of the participants practice spirituality in classrooms. By illuminating the spiritual language of humanistic and progressive philosophies, we may conclude that the nature and spiritual discourse of each philosophy as well as their practical implications should be articulated in teacher education programs to fulfill the everlasting growth of an individual as an utmost purpose of education.
\end{abstract}

Keywords: EFL teacher, educational philosophy, spirituality in education 


\section{INTRODUCTION}

An integral part of educators' growth is self-awareness. The benefits of selfawareness and reflection are well documented in the studies conducted in this area (e.g. Allan \& Driscoll, 2014; Dewey, 1944; Hawkins, 1974; Osterman \& Kottkamp, 1993). Rodgers (2002) characterized reflection as "a meaning making process that happens in community and values the growth of oneself and of others" (p.845). Since self-awareness through reflection is a progressively cumulative endeavor, it acts as a means to the "intellectual, moral, and emotional growth of the individual" (Dewey, 1944, p.99). The practice of reflection illuminates one's beliefs, values, and attitudes. By the act of reflection, educators go one step beyond their cognition and build the foundation to explore their educational philosophies.

Different schools and orientations of educational philosophies proposed by various theorists (e.g. Dewey, 1944; Freire, 1993; Piaget, 1965, Rogers, Stevens, Gendline, Shlien \& Van Dusen, 1967; Thorndike, 1944) are the essence of theoretical and practical decision-making in education. Educational philosophy is like a root that constructs not only the knowledge of learners but also their attitudes and values, after they go on to use their education in their thoughts and incentives for action.

The practice of second language teaching (SLT) is not an exception in this regard. English as foreign language (EFL) educators also need to be conscious of their underlying philosophical practice since learning a foreign language exposes students to various social, political, spiritual, and religious issues.

Based on the sociocultural perspective of second language learning derived from Vygotsky's work (1962), language learning is a perfect type of social activity. The main concepts he proposed for learning stressed the importance of philosophy and value in directing second language learning. The Vygotskian concepts of language as an important symbolic tool for mediation, scaffolding, and other regulation for attending to the key features of the environment, acquiring new concepts through social interaction (microgenesis), and the context of the activity (activity theory) point toward the significance of the philosophy of education in guiding the foreign language learner step by step in going through the complex process of acquiring a completely new and vast values and goals. Noddings (2002) asserted his concern that researches in applied linguistics lack the investigatory approach to teaching as a profession burdened with values. Watson-Gegeo (2004) stressed that spirituality must be one of the research inquires into language as it is aptly illustrated in her quotation that "spirituality will become a significant dimension of the paradigm shift in the human and social sciences that revolutionizes the way we view mind, language, epistemology, and learning" (p.343). In a similar vein Bradley (2011b) viewed spirituality for second language educators "in terms of personal and classroom transformation, as well as ethical and connective pedagogy" (p. 368). Other scholars (Cranton \& Carusetta, 2003; Glazer, 1999; Nash, 2001, 2002; Pajak\& Blase, 1989; Tisdell \& Tolliver, 2003) believed that spirituality positively flourish the teaching practice. 
Palmer (2003) defined spirituality as "the eternal human yearning to be connected with something larger than our own egos" (p.377). Spirituality is focusing on nonmaterial elevated realities and a deep perception of the aim and value of the creation and life. Perusal on this position leads the individual to regulate the sphere of one's activity in a way transcendence requires us to do and as a result spirituality will be gained. Such kind of viewpoint can only be incorporated in the classroom if only the philosophy of education of teachers are probed and altered, since educational philosophy is the pillar on which ideas, beliefs, and values are established (Galbraith, 2004). Philosophies of education enable teachers to weave a meaningful pattern out of curriculum and teaching materials that will be congruent with the self, society, and the world. In other words, they provide guidelines for the practice of teaching. These guidelines will eventually connect the three angles of the teaching triangle (i.e. the teacher, the student, and the subject matter). Consequently, they will be connected to meanings and purposes outside of the classroom. The roles that meanings and purposes play are the same as what the function of spirituality is such as responsibility, development, transformation, equilibrium and authentic relationships with the whole universe, etc. Philosophy subsumes spirituality and no educator will be free of beliefs about values (the axiological questions). Spirituality will be operative in terms of educators' professional motivation even if it is among their hidden assumptions and presupposition.

Despite the significant role of philosophy in education especially for EFL/ESL teachers (Boone, Gartin, Buckingham, Odell \& lawrence, 2001; Decoux, Rachal, Leonard \& Pierce, 1992; Lehman, 2003; Spurgeon \& Moore, 1994; Zandvanian, 2009) and the paucity of research on spirituality and language pedagogy (Bradley, 2011; Foster, 1997; Galeh \& Dorcheh, 2015; Marler \& Hadaway, 2002), further research on philosophical position and spiritual beliefs of EFL practitioners is necessitated. In the following section, the educational philosophies, and the role of spirituality in education are elaborated on.

\section{LITERATURE REVIEW}

\subsection{Philosophies of Education}

Philosophy of education influences and directs the various practices of educators in personal, public, and professional dimensions. The aim of philosophy is to shed light on our unconscious beliefs and principles and gives an oversight to hidden assumptions that control our actions and values (Kauchak \& Eggen, 2011). Five traditional schools of philosophies which are the basis of philosophies of education are Idealism, Realism, Pragmatism, Existentialism, and Reconstructionism. Philosophies of education including Liberal, Behavioral, Progressive, Humanistic, and Radical have their roots in these traditional schools of philosophy (Zinn, 2004). A brief description of educational philosophies is presented below.

\subsubsection{Liberal Education}

The liberal philosophy of education is influenced by idealism. In this approach the focus is on conscious reasoning through identifying with a superior, absolute, and perfect being. Socratic teaching method, discussion, and introspection are used to 
develop individual intellect and instructions are teacher-centered. Idealists believe that mental, spiritual reality, and value ultimately reaches to God which is absolute. They give importance to the world of reality that is perceived by the mind, not the natural world that is perceived through senses. Liberal education emphasizes higher order thinking and the transmission of absolute truth since the material world is constantly changing (Zinn, 2004).

\subsubsection{Behavioral Education}

Other terms associated with behaviorism are positivism and realism. The importances of environment on conditioning the correct behavior, manipulation of the stimulus, and the physical objects as the ultimate reality are purposes of this philosophy. In this method the teacher is the controller, and the guide. Teaching methods include demonstration, recitation, drilling, experimentation, and masterylearning (Richards \& Rodgers, 2001). According to behaviorists environment determines the human behavior, and by manipulating the environment, the behavior would be changed. Values are attributed to scientific research and natural law. These values are changeable because they are subject to senses and experience. In this form of practice, learners are expected to be reinforced and feedbacked after they practice the new behavior.

\subsubsection{Progressive Education}

Pragmatism or experientialism main focus is on experience. Since they believe reality is changing constantly, problem solving is best learned through applying our experiences and thoughts to overcome obstacles. Universe is dynamic and evolving since thought must lead to action (Zinn, 2004). Teaching methods in progressive education are problem solving, cooperative learning, and project work. The teacher role is an advisor and a guide rather than an authority. Since reality is constantly changing and education is a continuous dynamic growth for an individual that is everlasting, curriculum should be learner-centered (Larsen-Freeman \& Anderson, 2011).

According to pragmatists, knowledge and meaning are valuable only when they have practical consequences. In pragmatic philosophy, values are only attributed to the outcomes of one's action or experience. Values are taken from the interaction between individual and society and not taken from any absolute reality; rather they are enriched by experience and action. The goal of progressive education is improvement beyond the classroom, and as a result preparing learners to improve society. Teacher is a guide or organizer of learning for doing real-world tasks (Conti, 2007).

\subsubsection{Humanistic Education}

Humanism is associated with existential philosophy. Humanistic psychology places the individual at the center of focus who is capable for growth, responsible to make choices, and able to research for personal meaning. That is, it is the individual who chooses the values. Educational values of existentialism emphasize students' capacity for decision making since they should be able to clarify their views when 
confronted with others' views. The teacher is facilitator and among the teaching methods of humanist educators are experiential learning, discovery method, and team teaching which lead learners to self-actualization, freedom, and autonomy (Elias \& Merriam, 1995).

\subsubsection{Radical Education}

The aim of reconstructionism is to create a better and new social order. Proponents of radical education defend overcoming oppression by going beyond the social norms, and improving human condition by critical thinking and awareness. They view teaching as empowering students to improve the world through critical inquiry into real social problems. Reconstructionists believed that education has a social function that should reconstruct both education and society. Teacher as a coordinator helps students to become an active agent in social change by emphasizing equality, and students' autonomy (Zinn, 2004).

\subsection{Spirituality and Education}

Linking spirituality and education can be a risky, full of misinterpretation, and even a fuzzy endeavor. Moreover, it should not be linked with proselytizing (Bradley, 2011a). Although spirituality is highly identified with religion (O'Sullivan, 2003), it is the essence of messages of all faith. Lerner's "emancipatory spirituality" (2000, p.174) emphasizes pluralism and toleration for all ideologies and worldviews that acknowledge different cultures, religions, and traditions. This view is also shared by Noddings (2002) and Postman (1995). Palmer (1998) described objectivists' point of view toward spirituality as: "Any way of knowing that requires subjective involvement between the knower and the known is regarded as primitive, unreliable, and even dangerous" (p.52). Likewise, Tisdell (2003) believed that whenever spirituality comes into focus of attention, educators thought that "it is only scientific thought that is worthy of attention" (p.25).

Spirituality is a sensitive term to define. Palmer (2003) expressed that "spirituality is an elusive word with a variety of definitions" (p.377). Spirituality in relation to different aspects of social experience, characteristic trait, cognition, and relationship is dynamically interwoven, created, and recreated into different levels of consciousness (Wilber, 2000). Therefore, spirituality could be referred to as a relative concept in terms of "connection with oneself, others, and the transcendent" (Galeh \& Dorcheh, 2015, p.1810) as well as "freshness of perception" (Webster, 1996, p.249). Jones (2005) broadly defined spirituality as "our most authentic relationships to self, others, the universe, and the transcendent influence our personal health on all levels, the health of our communities, our nations, and the world" (p.1). Another explanation of spirituality put forward by Palmer (1993) is "compassion that is responsibility, involvement, mutuality, and accountability toward each other" (p.9).

Based on the clarifications stated above, exploring spirituality put forward new and different means of awareness for teacher and the learner, in addition; it opens gateways of knowledge and experience that in general benefits the educational institutions and society. The aim of education stated by Palmer (1999) as 
"empowerment, liberation, transcendence, about renewing the vitality of life"(pp.1819) aptly reinforce the point of spirituality in education to connect the teacher, the student, and the subject matter at the classroom level and make students aware of the eminent, higher meaning, and purpose beyond the classroom.

In the field of foreign language education, the studies done in this regard are only limited to language educators in terms of religious issues (Varghese \& Johnston, 2007; Wong \& Canagarajah, 2009; Griffith, 2004), but there is a lack of inquiry into the practice of spirituality in Iranian EFL classrooms and how it affects teacher practices. Regarding spirituality as vital, rejuvenating, and transformative force and philosophy as the foundation of values, beliefs and practices, the present study aims to investigate educational philosophies and spirituality of Iranian EFL teachers.

As a result, the following research questions guide the investigation:

1) What are the educational philosophies of Iranian EFL teachers?

2) Do EFL teachers incorporate spirituality in their English teaching practice?

3) How spirituality can affect EFL educators practice?

\section{RESEARCH METHODOLOGY}

\subsection{Research Context, Participants, and Sampling Procedure}

The participants in this study were 240 Iranian EFL teachers, teaching at different language institutes at Shiraz city, Iran. Fifty percent of the participants are male teachers and the rest are female ones. A complete list of Shiraz city language institutes from four districts was taken from the ministry of education. Twenty four institutions ( $n=24: 12$ male and 12 female), that is six institutes $(n=6: 3$ male and 3 female) from four districts were selected randomly. With the consent of the managers of language institutes, ten English adult language teachers were chosen randomly among the adult educators in each male and female institute to participate in the study.

\subsection{Materials and Instruments}

Two types of data obtained for the present study were the Philosophy of Adult Education Inventory (PAEI), and qualitative questions regarding second language education and spirituality.

\subsubsection{Philosophy of Adult Education Inventory (PAEI)}

The Philosophy of Adult Education Inventory/ PAEI (Zinn, 1983) contains 15 incomplete sentences. Each sentence is followed by five incomplete sentences and the totals of sentences include 75 responses. The inventory uses a 7-point Likert type scale. The responses to each statement ranges from 1 (Strongly Disagree) to 7 (Strongly Agree) with a neutral point of 4. According to Zinn, the statements in PAEI represent five philosophies of education (liberal, behaviorist, progressive, humanistic, radical) adapted from Elias and Merriam (1995). The instrument had been reported as valid and reliable (Gay \& Airasian, 2000; Salkind, 2008; Slavin, 2012; Zinn, 1983). For the present study, the reliability index of the questionnaire estimated through Cronbach alpha was .83 which was satisfactory. 


\subsubsection{Qualitative questions regarding spirituality and SLT}

In order to understand whether EFL teachers incorporate spirituality in their English teaching practice and the effect of spirituality in their classroom, the following two general questions were posed and the teachers are asked to write their response in detail to each question:

1) Do you incorporate spirituality in your English teaching practice?

Please describe your answer in detail.

2) How spirituality can affect your practices in the classroom?

\subsection{Data Collection and Data Analysis}

This sample survey (cross-sectional) study employed both quantitative and basic qualitative / interpretive data. This kind of mixed method design used concurrent triangulation to collect the qualitative and quantitative data at the same time and use the inferences from both kinds of data to converge in the conclusion. Quantitative and qualitative were collected from all the participants.

To answer the first research question descriptive statistics for the frequency and percentage of educational philosophies was used. The answers to the second and third research questions; dealing with practice and effect of spirituality, were examined to find similarities, differences, and categories among the positions of teachers. The researcher went through three phases of familiarizing, coding, and interpreting. In the first phase, the researcher read and reread the answers. Next, the substantive categories and themes were identified. The actual response of participants were used (in vivo codes) to find the themes. Finally, a comparison was made between the categories found for first and second questions. Since there is no priori imposition on the findings, in turn the educational philosophies and the point of views of teachers toward spirituality were linked together and presented in the discussion section.

\section{FINDINGS}

\subsection{Educational Philosophies of Adult Iranian EFL Teachers}

In order to determine the educational philosophies of EFL teachers, the scores of respondents to each item, from 1 to 7 were added up and the subtotals ranging from 15 to 105 were calculated (Zinn, 1983). Over half (60\%) of the participants dominant philosophy was progressive philosophy with 144 respondents. The second most frequent educational philosophies were the combinations of progressive and humanistic (28\%) with 67 respondents. Twenty nine respondents (12\%) identified with humanistic philosophy. As the data analysis shown, none of the educators $(0 \%)$ had liberal, behavioral, and radical philosophies. Therefore, the results demonstrated that progressivism was mostly preferred by educators. In addition, a combination of progressive and humanistic philosophies and humanistic philosophy alone to some extent were adopted by teachers. It appears that there was an approximate not equal balance in inclination toward progressivism and humanistic philosophies, an important point that must be reconsidered in light of the qualitative research results and the linkages of spirituality and philosophy. 


\subsection{Incorporation of Spirituality in English Teaching Practice}

Qualitative analysis of the teachers' response to the second research question has indicated that participants had three positions regarding incorporation of spirituality in EFL classrooms.

The first group finds no relationship between language and spirituality. "Language for the sake of language" (Teacher 23) is one of the written responses of participants. Similar quotations found among the answers of the proponents of this viewpoint:

"I want to enable students to learn four essential language skills, which is reading, writing, listening, and speaking." (Excerpt 1, Teacher 10)

"Whenever I enter into the classroom, I just thought about how to give the most comprehensive information to my student learning English, that is no room left anymore to think about something else rather than teaching English language itself" (Excerpt 2, Teacher 52)

The second group was concerned with values. This statement clearly represented this stance: "Spirituality is something that always lingers on my mind, I have to go beyond merely language teaching" (Teacher 25). But the entire group continues to mention that due to political, institutional, and diverse learner's characteristics are afraid of being "stereotyped" (Teacher 60) by institutional managers, learners, and parents if they mention the values and go beyond merely teaching English and "discussing moral, political, religious, and personal matters" (Teacher 85). It seems that teachers felt distressed and stifled to talk about spirituality. The excerpts below clearly illustrate the point of view of teachers toward spirituality:

"Throughout my career as an adult teacher, I almost teach the same subject matter, what annoys me is not the teaching the same course or subject to students, but it is the lack of an essential aspect that any education must transfer to students. That is after the class, I told myself, I just only taught how to speak, write, listen, and read in a new language, but that is not enough! I know education and learning should be lifelong, that is, it should contribute to growth of the individual in a long term and foreign language teaching is not an exception. But political, institutional, and labeling is something that always restrains our actions." (Excerpt 3, Teacher 17)

"Spirituality and spiritual values are global terms that have an important position not only in life but also in education. It is the education that should prepare individuals for life. I am the eager proponent of such practices if contextual factors (all the parties involved in learning, teaching, and management) do not hold us back." (Excerpt 4, Teacher 90)

Finally, the teachers of the last group were those that equate spirituality with teaching religious values in English; that is Islam in the context of the study, and 
stated that "If the subject of the lesson is about religion, we talk about it" (Teacher 92). For example one of the EFL educators expressed that:

"By spirituality, probably you mean religious issues. For that purpose, we could have a separate course, what is called English for specific purpose. In that course, they could learn about how to discuss religious matters in English." (Excerpt 5, Teacher 37).

\subsection{The Effect of Spirituality in EFL Classroom}

Regarding the effect of spirituality, the teachers' assertions were divided into two classifications. The respondents of the first category believed that spirituality should be defined first. In other words, they don't know whether to "match the term with religion" (Teacher 7) or it is the kind of "knowledge transfer to students about world's religions" (Teacher 31). Since this group didn't understand how it is possible to operationalize spirituality in classroom practices, accordingly most of them suggested that teachers should be instructed in teacher training courses, workshops, and meetings to learn the implications of spirituality in theory and practice for second language teaching.

As a matter of fact, the second group mentions the same standpoint. Furthermore, in contrast to the first group the effect of spirituality was more clearly articulated. One of the teachers mentioned:

"We have to do more than to teach English. I mean to teach something beyond the everyday, mundane world, that thing is spirituality." (Excerpt 6, Teacher 38)

Another participant clearly clarified that "spirituality is what I am looking for, because throughout years of my experience in EFL teaching, I told myself what it is that gives meaning to my discipline" (Teacher 91). Moreover, this quotation explains suitably the effect of spirituality on education:

"Deepening our understanding about ourselves and helping students to reflect on their own perception are the result of spirituality. For this reason, it gives a fresh air and a creative force to the classroom." (Excerpt 7, Teacher 55)

A reanalysis of the qualitative information revealed that those teachers who didn't know how to operationalize spirituality in the classroom or referred to the vagueness of the term itself were those teachers who were only concerned with teaching language skills and those equating spirituality directly with teaching how to use ones English knowledge to speak, write, read, and listen whenever the subject of religion comes into focus. On the other hand, the participants who explicitly expressed the effect of spirituality were those teachers concerned with values and pointed toward the restrains. On the whole, based on the participants' response, none of them incorporate spirituality in their classrooms; nonetheless they have a rather positive outlook toward the effect of spirituality in EFL classes. 


\section{DISCUSSION AND CONCLUSION}

This study was aimed at exploring educational philosophies as well as practice, and stance of Iranian EFL teachers toward spirituality. The results suggested that the dominant philosophy of education of Iranian EFL teachers was progressive education. Combination of progressive and humanistic philosophies and humanistic philosophy were to some degree establish a balance with progressivism. Regarding the incorporation and the effect of spirituality in EFL classrooms, participants set up various groups which overall point toward the fact that none of them practice spirituality due to the lack of clear understanding of the concept or inhibitions. On the basis of the findings, the following discussions are presented and the relevant conclusions are made.

\subsection{Regarding Educational Philosophies and Spirituality}

The core of any successful education and educating is the reconciliation of theory/value with practice both for teachers and students. Human perfection which is the goal of learning goes hand in hand with spirituality as transcendence and a new outlook on life (Nash, 2002) since both contributes to transformation. A closer look at the controlling philosophies of education of Iranian EFL teachers that is progressive, humanistic or the combination of both reveal that spirituality has a place in each of these educational philosophies based on the link between spirituality and education discussed by various scholars (e.g. Glazer, 1999; Nash, 2001; Palmer, 2003; Watson-Gegeo, 2004).

In humanism, Rogers (1951) put forward the concept of self-actualization as the ultimate goal of education. A fully-functioning person that is someone who is always in touch with his/her inner and outer experiences tries to make a balance or be congruent with oneself, the actual reality, and the ideal self he/she wants to achieve. This process is dynamic as spirituality is a never ending connection "in relationship and in union" (Miller, 1999, p.10). Practices common to humanistic education are inquiry, questioning, and exploration and the teacher has a role of facilitator which directly contributes to cognitive and affective development of students. The concepts of self-actualization, a fully-functioning person, congruence with oneself, the actual, and the ideal self, and dynamism are overlapping constructs with the aim of spirituality.

Similarly, linking action and knowledge and connecting theory and practice are the purpose of both spirituality and pragmatism. The aim of progressive education is to extend the field of experience and knowledge. As a matter of fact, it creates an atmosphere of forward movement for students. According to Dewey (1944) education "reconstructs or reorganizes the experience" (p.74). Since any education in nature is a kind of experience, pragmatists holds that experience should not remain static but should lead to growth and broadens its field. This is only possible through reflection on experience. By reflection, Dewey (1938) means continuity and connection of extracting meanings among and between the experiences, between the experiences and one's and the other's knowledge. Consequently, reflection leads to action, seeking solution, and formulating a theory, so that the process moves the 
learner to equilibrium because the solution and the theory tested in action disclose their weaknesses and strengths and the learner constantly goes through the cyclical process of reflection.

This process is close to Piaget's schema building. Reflection is an emotional, cognitive discipline which is guided by the teacher, the student, and the subject matter as spirituality is a "deep connection" (Jones, 2005, p.2) between these three important factors like "a rope showing us the way home" (Palmer, 2004, p.2). The process of meaning-making from experience is associated with the soul: "if in the process the individual loses his own soul: loses his appreciation of things worthwhile, of the values to which these things are relative" (Dewey, 1938, p.49). In the same way, Nash (2001) believed that "the best pedagogy aims first at the heart and soul before it can ever find its way to the mind" (p.9). As the above explanations illustrate, there is also a room for the practice of spirituality in the progressive education (Bradley, 2011b) as concepts such as continuity, connection, equilibrium, and reflection aim to fulfill the objective of philosophy to construct a balanced individual in social and personal deeds (Bradley, 2011b; Palmer, 1999, Tisdell, 2003).

The fact that teachers are not aware of what spirituality exactly refers to and those that mentioned the positive vital force of spirituality but due to constraints do not practice spirituality could be attributed to lack of awareness of the potentiality of their philosophy in assumption and action. In other words, they must be getting acquainted with theories, principles, and practices of the progressive and humanistic or the combination of both at the conscious level. Equally important, it is essential to highlight the spiritual language that each of these philosophies possess. The teacher "must know, at the deepest personal level, the stance he takes in regard to life" (Rogers, 1969, p.218). If the educator fails to know one's values, he/she will not be able to know what kind of learner will emerge from his/her education and consequently would be unsuccessful in the professional career and cultural values. If spirituality is the core of all faith, a dynamic, transformative education will led learners to implement and connect their education (EFL practices) with the values of their own faith.

\subsection{Pedagogical Implications and Suggestions for Further Research}

In terms of potential pedagogical practices, the present study offers some useful implications for both teacher education programs and teachers. First, the findings of the study suggest that teachers were not fully informed of the underlying nature of knowledge, value, and reasoning of their educational philosophies. This indicates an immediate need for teacher educators to clearly articulate the nature of characteristics of each philosophy to teachers, spiritual discourse that they espouse, and their practical applications in the classroom. Furthermore, it is proposed that teachers write reflections on their teaching practices or keep journal diaries. Subsequently, these reflections would be discussed and became the subject of exploration in light of teachers' educational philosophy by the teacher, among the teachers, and the teacher educators. 
It should be acknowledged that due to the practical considerations, the study actually has some limitations. Firstly, an analysis of the quantitative and qualitative data collected from greater number of participants will be necessary. In the present study, no attempt was made to include the viewpoints of teacher educators and cultural aspects of the same constructs or to conduct an extended classroom observation of teachers with different philosophies and identities. Furthermore, the role of religious context of the study should be considered. Also, taking into account the EFL learners and parents viewpoints toward spirituality can reveal illuminating facts. A future studies in ESL/EFL context in this regard help the practitioners in the field to go beyond "hows and whats" of teaching and involved them with "why" (Nash, 2001, p.3) to deepen their understanding of how to connect the intellect to the transcendence.

\section{REFERENCES}

Allan, E. G., \& Driscoll, D. L. (2014). The three-fold benefit of writing: Improving program assessment, student learning, and faculty professional development. Assessing Writing, 21, 37-55. http://dx.doi.org/10.1016/j.asw.2014.03.001

Boone, H., Gartin, S., Buckingham, C., Odell, K., Lawrence, L. (2001). Philosophies of adult education as practiced by agricultural education teachers. 28th Annual Agricultural Education Research Conference, December 12, 2001, pp.526-538.

Bradley, C. A. (2011a). Spirituality and language education: An introduction. Journal of the Faculty of Global Communication, University of Nagasaki, 12, 1-10.

Bradley, C. A. (2011b). An inquiry into relationship between spirituality and language pedagogy (Doctoral dissertation). Available from ProQuest Dissertations and Theses database.

Conti, G. (2007). Identifying your educational philosophy: Development of the philosophies held by instructors of life-long learners (PHIL). MPAEA Journal of Adult Education, 36(1), 19-35.

Cranton, P., \& Carusetta, E. (2004). Developing authenticity as a transformative process. Journal of Transformative Education, 2(4), 276-293.

DeCoux, V., Rachal, R., Leonard, R., Pierce, L. (1992). A Quantitative Examination of Philosophical Predilecations of Adult Education Graduate Students. Paper presented at the Annual Meeting of the American Association for Adult and Continuing Education. Anaheim

Dewey, J. (1938). Experience and education. New York: Collier Books, Macmillan.

Dewey, J. (1944). Democracy and education. New York: Free Press.

Elias, J. L. \& Merriam, S. B. (1995). Philosophical foundations of adult education $\left(2^{\text {nd }}\right.$ ed.). Malabar, FL: Krieger Publishing Company.

Foster, M. (1997). What I learned in Catholic school. In C.P. Casanave \& S. Schecter (Eds.), On becoming a language educator: Personal essays on professional development (pp. 19-28). Mahwah, NJ: Erlbaum.

Freire, P. (1993). Pedagogy of the oppressed (M. B. Ramos, Trans.). New York: The Continuum International Publishing Group. 
Galbraith, M. (2004). The teacher of adults. In M.W.Galbraith (Ed.), Adult learning methods ( $3^{\text {rd }}$ ed.).Malabra, FL: Kreiger Publishing Hiemstra, R. (2011).

Galeh, S. M. \& Dorcheh, H. H. (2015). Spirituality and second language education. Theory and Practice in Language Studies 9(5), 1809-1814. doi: http://dx.doi.org/10.17507/tpls.0509.06

Gay, L. R., \& Airasian, P. (2000). Educational research: Competencies for analysis and application. ( $6^{\text {th }}$ ed.). Columbus, $\mathrm{OH}$ : Merrill.

Glazer, S. (Ed.). (1999). The heart of learning: Spirituality in education. New York: Jeremy P. Tarcher/Putnam.

Griffith, T. (2004). Unless a grain of wheat... TESOL Quarterly, 38(4), 714-716.

Hawkins, D. (1974). The informed vision: Essays on learning and human nature. New York: Agathorn Press.

Jones, L. (2005). What does spirituality in education mean? Journal of College and Character 7 (6), 1-7. doi: http://dx.doi.org/10.2202/1940-1639.1485

Kauchak, D. and Eggen, P. (2011). Introduction to teaching: Becoming a professional $\left(4^{\text {th }}\right.$ ed.). Boston: Pearson Education, Inc.

Larsen freeman, D. \& Anderson, M. (2011). Techniques and principles in language teaching $\left(3^{\text {rd }}\right.$ ed.). Oxford University Press.

Lehman, M. (2003). Interrupting the reflective practitioner: Discovering the espoused philosophies and theories and theory-in- use of 13 adult educators. (Doctoral dissertation). Available from ProQuest Dissertations and Theses database.

Lerner, M. (2000). Spirit Matters. Charlottesville, VA: Hampton Roads Publishing Company.

Marler, P. L., \& Hadaway, C.K. (2002). "Being religious" or "Being spiritual" in America: A zero-sum proposition? Journal for the Scientific Study of Religion, 41(2), 289 - 300. doi: 10.1111/1468-5906.00117.

Miller, R. (1999). Holistic education for an emerging culture. In S. Glazer (Ed.). The heart of learning: Spirituality in education (pp. 189-201). New York: Tarcher/Putnam.

Nash, R. J. (2001). Religious pluralism in the academy: Opening the dialogue. New York: Peter Lang.

Nash, R. J. (2002). Spirituality, ethics, religion, and teaching: A professor's journey. New York: Peter Lang.

Noddings, N. (2002). Caring: A feminine approach to ethics and moral education ( $2^{\text {nd }}$ ed.). Berkeley, CA: University of California Press.

Osterman, K., F., \& Kottkamp, R., B. (1993). Reflective practice for educators: Improving schooling through professional development. Newbury Park, CA: Corwin Press.

O' Sullivan, E. (2003). The project and vision of transformative education: Integral transformative learning. In E. O'Sullivan, A. Morrell, \& M. A. O'Connor (Eds.), Expanding the boundaries of transformative learning (pp. 1-12). New York: Palgrave. 
Pajak, E., \& Blase, J. L. (1989). The impact of teachers' personal lives on professional role enactment: A qualitative analysis. American Educational Research Journal, 26(2), 283-310.

Palmer, P. (1993). To know as we are known: A spirituality of education. New York: Harper Collins Publishers.

Palmer, P. (1998). The courage to teach. San Francisco: Jossey-Bass.

Palmer, P. (1999). The grace of great things: Reclaiming the sacred in knowing, teaching, and learning. In S. Glazer (Ed.), The heart of learning: Spirituality in education (pp. 15-32). New York: Jeremy P. Tarcher/Putnam.

Palmer, P. (2003). Teaching with heart and soul: Reflections on spirituality in teacher education. Journal of Teacher Education, 54(5), 376-385.

Palmer, P. (2004). A hidden wholeness: The journey toward an undivided life. San Francisco: Jossey-Bass.

Piaget, J. (1965). The language and thought of the child. New York: World Publishing Co.

Postman, N. (1995). The end of education: Redefining the value of school. New York: Vintage Books.

Richards, J. C. \& Rodgers, T. (2001). Approaches and methods in language teaching $\left(2^{\text {nd }}\right.$ ed.). Cambridge University Press.

Rodgers, C. (2002). Defining reflection: Another look at John Dewey and reflective thinking. Teachers College Record, 4(104), 842-866.

Rogers, C. (1951). Client-centered therapy: Its current practice, implications and theory. London: Constable.

Rogers, C. R., Stevens, B., Gendlin, E. T., Shlien, J. M., \& Van Dusen, W. (1967). Person to person: The problem of being human: A new trend in psychology. Lafayette, CA: Real People Press.

Rogers, C. (1969). Freedom to learn. Columbus, Ohio: Merrill.

Salkind, J. N. (2009). Statics for people who (think they) hate statics $\left(3^{\text {rd }}\right.$ ed.). Los Angeles, CA: Sage Publications.

Slavin, R. E. (2012). Educational psychology: Theory and practice (10 ${ }^{\text {th }}$ ed.). Boston: Pearson.

Spurgeon, L., Moore, G. (1994). The educational philosophies of training and development professors, leaders and practitioners. Paper presented at American Vocational Association.

Tisdell, E. J. (2003). Exploring spirituality and culture in adult and higher education. San Francisco: Jossey-Bass.

Tisdell, E., \& Tolliver, D. (2003). Claiming a sacred face: The role of spirituality and cultural identity in adult higher education. Journal of Transformative Education, 1(4), 368-392.

Thorndike, E. L., \& I. Longe. (1944). The teacher's world book of 30,000 words. New York: Teachers College, Columbia University.

Varghese, M., \& Johnston, B. (2007). Evangelical Christians and English language teaching. TESOL Quarterly, 41(1), 5-31.

Vygotsky, L. S. (1962). Thought and language. Cambridge, MA: MIT Press. 
Watson-Gegeo, K. (2004). Mind, language, and epistemology: Toward a language socialization paradigm for SLA. The Modern Language Journal, 48(3), 331350.

Webster, D. H. (1996). Spiders and Eternity: Spirituality and the Curriculum. In Best, R. [Ed.], Education, Spirituality and the Whole Child (pp.245-259). London: Cassell.

Wilber, K. A. (2000). Theory of Everything. Boston: Shambhala.

Wong, M. S., \& Canagarajah, S. (Eds.). (2009). Christian and critical English language educators in dialogue: Pedagogical and ethical dilemmas. New York: Routledge.

Zandvanian, A. (2009). Recognition and analysis of the educational philosophy of Yazd province adult education instructors. Proceedings of the $2^{\text {nd }}$ ICTL. INTI University College, Malaysia, 1-7.

Zinn, L. M. (1983). Development of a valid and reliable instrument to identify a personal philosophy of adult education. Dissertation Abstracts International, 44, $1667 \mathrm{~A}-1668 \mathrm{~A}$.

Zinn, L. M. (2004). Exploring your philosophical orientation. In M.W. Galbraith (Ed.), Adult learning methods ( $3^{\text {rd }}$ ed.), 39-74. Malbar, FL: Kreiger Publishing Company. 